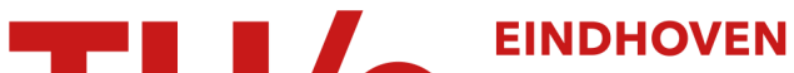 \\ UNIVERSITY OF \\ TECHNOLOGY
}

\section{Subsidy and entry : role of licensing}

Citation for published version (APA):

Mukherjee, A. (1999). Subsidy and entry : role of licensing. (ECIS working paper series; Vol. 9912). Technische Universiteit Eindhoven.

\section{Document status and date:}

Published: 01/01/1999

\section{Document Version:}

Publisher's PDF, also known as Version of Record (includes final page, issue and volume numbers)

\section{Please check the document version of this publication:}

- A submitted manuscript is the version of the article upon submission and before peer-review. There can be important differences between the submitted version and the official published version of record. People interested in the research are advised to contact the author for the final version of the publication, or visit the $\mathrm{DOI}$ to the publisher's website.

- The final author version and the galley proof are versions of the publication after peer review.

- The final published version features the final layout of the paper including the volume, issue and page numbers.

Link to publication

\section{General rights}

Copyright and moral rights for the publications made accessible in the public portal are retained by the authors and/or other copyright owners and it is a condition of accessing publications that users recognise and abide by the legal requirements associated with these rights.

- Users may download and print one copy of any publication from the public portal for the purpose of private study or research.

- You may not further distribute the material or use it for any profit-making activity or commercial gain

- You may freely distribute the URL identifying the publication in the public portal.

If the publication is distributed under the terms of Article $25 \mathrm{fa}$ of the Dutch Copyright Act, indicated by the "Taverne" license above, please follow below link for the End User Agreement:

www.tue.nl/taverne

\section{Take down policy}

If you believe that this document breaches copyright please contact us at:

openaccess@tue.nl

providing details and we will investigate your claim. 




Eindhoven Centre for Innovation Studies, The Netherlands

Working Paper 99.12

"Subsidy and Entry: Role of licensing"

by

A. Mukherjee (ECIS)

October 1999 


\title{
Subsidy and Entry: Role of Licensing
}

\author{
Arijit Mukherjee* \\ Technische Universiteit Eindhoven, The Netherlands \\ May, 1999
}

\begin{abstract}
The purpose of this paper is to highlight the role of a lump-sum subsidy in improving the welfare of a country. The lump-sum subsidy payment does not affect the marginal calculations of these firms; but, it can significantly alter other incentives of the firms. We show that the credible commitment of a domestic government for providing a lump-sum subsidy encourages technology licensing provided initial technologies of these firms are close enough. As a result, the government of the domestic country does not need to provide the subsidy at all and the commitment to the subsidy policy is enough to increase the welfare of the domestic country.
\end{abstract}

Key Words : Fixed cost, Subsidy, Technology licensing

JEL Classification : L13

"I would like to thank Kunal Sengupta and Sudipto Dasgupta for valuable suggestions. The author acknowledges the Netherlands Technology Foundation for financial support. The usual disclaimer applies. Correspondence to : Arijit Mukherjee, Technische Universiteit Eindhoven, Faculteit Technologie Management, Den Dolech 2, Postbus 513, 5600 MB Eindhoven, The Netherlands.

e-mail: A.Mukherjee@tm.tue.nl 


\section{Introduction}

The works on strategic trade policies are by now addressed several issues and showed the advantages of trade policies in an imperfectly competitive market. These works highlight that in case of imperfectly competitive world market, positive export subsidy or export tax may be an optimal policy. Considering per unit export subsidy or export tax these works show that these government policies of a country actually help a firm of that country to play more aggressively in the product market. Assume that there are two countries and each country has a firm to produce a good. Suppose that the firms compete in a 'third country'. Now, the imposition of per unit export subsidy or export tax by a government affects the marginal cost of production of the firm getting this subsidy and this helps to shift profit in favor of the firm of that country. Thus, by affecting the marginal calculations through per unit export subsidy or export tax, the government of a country may increase the domestic welfare. As a repesentative sample one may look at Spencer and Brander (1983), Brander and Spencer(1985), Eaton and Grossman (1986), Dick (1993), Neary (1994), etc. ${ }^{1}$

The earlier works, while addressing the role of strategic government intervention have concentrated on the per unit export subsidy or tax. ${ }^{2}$ The sensitivity of output to the per unit subsidy or tax makes these policies effective. The imposition of lump-sum subsidy or tax does not affect the optimal output choice and hence, becomes ineffective. In fact, in these models, imposition of lump-sum subsidy or tax reduces welfare of a country. Further, whether optimal policy is subsidy or tax depends on the nature of the interactions of the firms in the product market (i.e., Cournot or Bertrand). Sometimes, export subsidy becomes a highly debatable issue too in the trade organisations. As a whole, the previous works have highlighted the benefits of subsidy or tax which are related to the export amount but they have ignored government policy interventions those are not related to the amount of export.

While competing with a foreign firm in the world market, the government policies those are not related to the export amount may provide some strategic benefit too if it can affect other incentives of these firms. The present paper is devoted to address this issue. More specifically, we consider a lump-sum subsidy to show that even if it is not related to the export and does not affect marginal conditions directly, it can improve the welfare of a

\footnotetext{
${ }^{1}$ Some authors have focused on the trade policies when he firms sell their goods to either one or both of these countries. For example, one may look at Brander and Spencer (1981), Dixit (1984), Lee (1990), Bhattacharjea (1995), etc.

${ }^{2}$ The usefulness of both per unit and lump-sum subsidy or tax in the presence of asymmetric information about the cost of production has addressed in Qiu (1994).
} 
country by influencing other incentives like technology licensing between the firms. In what follows, the next section considers a scenario with countries - called domestic and foreign. Each of these countries consists of a firm. These firms have tehnologies to produce a product. We assume that the foreign firm has a relatively better technology compared to the domestic firm and production requires fixed cost. Like Spencer and Brander (1983) and Brander and Spencer (1985), etc., we consider that these firms compete in a 'third country'. The competition in a 'third country' helps us to show the role of lump-sum subsidy in increasing the welfare of the domestic country by altering the other incentives of these firms rather than by increasing competition in the domestic market and creating more consumer surplus.

If the fixed cost of production is sufficiently high then production may be unattractive for the domestic firm. Now, the domestic government can commit to a subsidy policy to make the production profitable by the domestic firm. This threat of entry from the domestic firm may encourage the foreign firm to license its better technology to the domestic firm and can make both the firms better-off. It turns out that as a result of licensing, the domestic government does not pay the subsidy at all. Further, it is important to note that irrespective of the nature of the game (i.e., Cournot or Bertrand) between these firms, it is optimal for the domestic government to subsidize its firm.

The rest of the paper is organised as follows. Section 2 describes the model and provides the result. Conclusion is given in section 3 .

\section{Model}

Consider that there are two firms - firm 1 and firm 2. Assume that these firms belong to the different countries. Firm 1 is situated at country 1, call foreign country, and firm 2 is situated at country 2 , call domestic country. Assume that firm 1 is technologically efficient compared to firm 2. Technologies are represented by the corresponding marginal costs of producion. Consider that firm 1 has a technology corresponding to marginal costs of production $c_{1}$ and firm 2 has a technology corresponding to marginal costs of production $c_{2}>c_{1}$. Assume that the production requires a fixed cost ' $F$ ' also. Like Brander and Spencer (1985), we consider that these firms compete in a 'third country'. ${ }^{3}$ Therefore, welfare of a country is same to the profits of the firm of that country.

We start with a situation where, given the marginal costs of production and fixed costs of production, only firm 1 gets prositive profit in the market. Hence, first basic

\footnotetext{
${ }^{3}$ We are ruling out the possibility of homogeneous good Bertrand competition if the market is characterised by price competition.
} 
assumption is

Assumption 1: $\Pi_{2}^{0}\left(c_{1}, c_{2}\right)<F<\Pi_{1}^{0}\left(c_{1}, c_{2}\right)$

where, $\Pi_{i}^{0}\left(c_{1}, c_{2}\right)$ is the operating profit (i.e., revenue minus variable costs of production) of firm $i$. Assumption 1 shows that without any government policy intervention, the market will be served by the firm 1 only as in this situation firm 2's optimal decision is not to produce anything. Now, we argue that government policy of country 2 may induce technology licensing from firm 1 to firm 2. This technology licensing in turn helps to improve the welfare of country 2. While considering government policy of country 2 , we restrict our attention to a lump-sum subsidy payment by the government of country 2 to firm 2. This implies that unlike the earlier works on strategic trade policy, subsidy does not affect the optimal output choce of the firms by reducing marginal cost of production. This is one major difference from the earlier works on strategic trade policies.

Thus, we consider the following game. At stage 1, governments of country 2 decides whether to subsidize firm 2 and in case of subsidization, it commits that it will compensate firm 2 if its operating profit is less than the fixed cost of production. ${ }^{4}$ In stage 2, firm 1 decides whether to go for a technology licensing deal. We consider that patent licensing contract consists of only up-front fixed fee (see, Katz and Shapiro, 1985, Marjit, 1990, Kabiraj and Marjit, 1992, 1993 and Marjit et al., forthcoming, etc., for this type of licensing contracts). ${ }^{5}$ The amount of fixed fee is determined by a Nash bargaining process. Then, in stage 3 , the firms take their production decisions like homogeneous goods Cournot duopolists.

Now, our second basic assumption is the following:

Assumption 2: $\Pi_{1}^{0}\left(c_{1}, c_{1}\right)=\Pi_{2}^{0}\left(c_{1}, c_{1}\right)>F$.

Assumption 2 shows that if firm 2 gets the technology from firm 1, then fim 2's operating profit can cover the fixed cost associated with prouction. Hence, in case of any technology licensing, the government of country 2 does not need to pay any subsidy to the firm 2 . However, technology licensing needs a payment by the firm 2 to firm 1 and the licensing creates more competition from firm 2 too by reducing its marginal cost of production. Hence, we have to look whether these firms will have any incentive for technology licensing

\footnotetext{
${ }^{4}$ We assume that the profits and the fixed costs of production are verifiable.

${ }^{5}$ Often it is not possible to monitor the rival's output as is necessary to enforce a royalty provision in a patent licensing agrement. This may be due to purely informational reasons or because of imitation possibility from the licensee after the technology transfer.
} 
deal at all.

Our, third basic assumption is

Assumption 3: $\Pi_{1}^{0}\left(c_{1}\right)>\Pi_{1}^{0}\left(c_{1}, c_{1}\right)+\Pi_{2}^{0}\left(c_{1}, c_{1}\right)$.

Assumption 3 implies that monopoly profit is greater than the duopoly industry profit. Therefore, industry profit decreases with more firms.

Before, going to the government policy intervention, first we look at the possibility of technology licensing without any such government policy. From Assumption 1 we know that in this situation the market will be monopolized by firm 1. Since, here monopoly profit is greater than the duopoly profit, firm 1 will have no incentive for technology licensing. Hence the welfare of country 2 is $W_{2}^{0}=0$.

Now, consider the game under government intervantion but with no technology licensing possibility. It will help us to focus the role of subsization in improving the welfare of country 2 by encouraging licensing between these firms. Since government commits to compensate the loss of firm 2 (i.e., the difference between the fixed cost of production and its operating profit), firm 2's net profit will be zero if it goes for production and we assume that if the firm is indifferent between production and no-production, then the firm will go for production. Then the net profit of firm 1 and firm 2 will be respectively

$$
\Pi_{1}^{g n l}=\Pi_{1}\left(c_{1}, c_{2}\right)-F \text { and } \Pi_{2}^{g n l}=0 .
$$

The welfare of country 2 will be

$$
W_{2}^{g n l}=-S<0
$$

where, $S=\left(F-\Pi_{2}\left(c_{1}, c_{2}\right)\right)$ shows that amount of lump-sum subsidy. Hence, we find that if there is no technology licensing but government intervention, then the commitment of country 2's government will encourage firm 2 to take part in poduction and it will be a duopoly of these firms. Therefore, in this situation firm 1 cannot maintain its monopoly status and has to compete with the firm 2 . However, under this situation, elfare of country 2 will be less compared to no government intervantion.

Now, we examine whether this change in the outcome at the production stage encourages firm 1 to license its technology to firm 2. Assuming that firm 1 has decided to license its technology to firm 2 and charging a Nash bargained up-front fixed fee, we have to solve the following expression for the price of the technology

$$
\max _{p}\left(\Pi_{2}^{0}\left(c_{1}, c_{1}\right)-F-p\right)\left(p+\Pi_{1}^{0}\left(c_{1}, c_{1}\right)-F-\Pi_{1}^{0}\left(c_{1}, c_{2}\right)+F\right)
$$


where, $p$ is the price of the technology to be paid by the firm 2 . Note, that after government policy intervention, the reservation payoff of the firm 1 and firm 2 are $\Pi_{1}^{0}\left(c_{1}, c_{2}\right)$ and 0 respectively. Further, due to the Assumption 2, government will not provide any subsidy in case the firms engage in technology licensing. Maximization of (1) gives

$$
p=\frac{\Pi_{1}^{0}\left(c_{1}, c_{2}\right)-F}{2}
$$

since, $\Pi_{2}^{0}\left(c_{1}, c_{1}\right)=\Pi_{1}^{0}\left(c_{1}, c_{1}\right)$.

While maximizing the expression (1), we have assumed that licensing will not worseoff any of these firms compared to no-licensing. Now, see whether this condition satisfies for both the firms. For this to satisfy we need

$$
\Pi_{2}^{0}\left(c_{1}, c_{1}\right)-F-p \geq 0(\text { for firm 2) }
$$

and

$$
\left.p+\Pi_{1}^{0}\left(c_{1}, c_{1}\right)-\Pi_{1}^{0}\left(c_{1}, c_{2}\right) \geq 0 \text { (for firm } 1\right) .
$$

Substituting (2) into (3) we get the required condition for firm 2 as

$$
2 \Pi_{2}^{0}\left(c_{1}, c_{1}\right)-\Pi_{1}^{0}\left(c_{1}, c_{2}\right)>F .
$$

Similarly, (2) and (4) give us the required condition for firm 1 as

$$
2 \Pi_{2}^{0}\left(c_{1}, c_{1}\right)-\Pi_{1}^{0}\left(c_{1}, c_{2}\right)>F .
$$

The conditions (5) and (6) are same. Therefore, with the satisfaction of (5) or (6) we can say that it is better for the firms to go for licensing deal than no licensing. While (5) or (6) puts a restriction on the upper limit on the fixed cost of production, Assumption 1 puts a lower bound on the value of fixed cost. Hence, for these two conditions to be consistent we need ${ }^{6}$

$$
2 \Pi_{1}^{0}\left(c_{1}, c_{1}\right)>\Pi_{1}^{0}\left(c_{1}, c_{2}\right)+\Pi_{2}^{0}\left(c_{1}, c_{2}\right) .
$$

Condition (7) implies that for our result we need that joint operating profit of these firms after technology licensing is greater than the joint profit operating profit before technology licensing. In otherwords, we need industry profit to increase due to technology licensing. Note that in this situation the government of country 2 will not subsidize the firm 2 actually but the net profit of firm 2 is $\Pi_{2}^{0}\left(c_{1}, c_{1}\right)-F-p>0$. Hence, welfare of country 2 increases with this commitment of the government of country 2 . We can summarize the above finding in the following proposition.

\footnotetext{
${ }^{6}$ Note that $\Pi_{1}^{0}\left(c_{1}, c_{1}\right)>2 \Pi_{2}^{0}\left(c_{1}, c_{1}\right)-\Pi_{1}^{0}\left(c_{1}, c_{2}\right)$. Hence, $\Pi_{1}^{0}\left(c_{1}, c_{2}\right)>\Pi_{1}^{0}\left(c_{1}, c_{1}\right)>F$ is also satisfied under condition (7).
} 
Proposition 2.1 Assume that $2 \Pi_{1}^{0}\left(c_{1}, c_{1}\right)>\Pi_{1}^{0}\left(c_{1}, c_{2}\right)+\Pi_{2}^{0}\left(c_{1}, c_{2}\right)$ and government of country 2 commits to compensate the loss of firm 2 arises from the difference of fixed cost of production and operating profit of firm 2. This commitment will induce technology licensing by firm 1 and improves the weafare of country 2 when the government of country 2 will not actually pay subsidy to firm 2.

The intuition of the above proposition is as follows. Due to government's commitment, fixed cost of production cannot prevent firm 2 from producing its output and as a result firm 1 faces a credible threat from the firm 2 in the output market. Facing this threat, it is better for firm 1 to license its technology under duopoly when technology licensing generates dividable surplus by increasing total industry profit. This technology licensing, will in turn, help firm 2 to cover the amount of fixed fee and makes its net profit and the welfare of country 2 positive. Therefore, if the domestic government knows there is a possibility of licensing if firm 2 takes part in production, then domestic government has the incentive for such committed subsidization policy. However, it is interesting to see that here subsidization helps to eliminate the constraint due to the fixed cost of production but it does not affect the per unit production cost of firm 2. One may also note that even if social valuation and private valuation of subsidy differ (see Neary, 1994), the government will always decide to subsidize firm 2. This difference in valutaion, however, will not matter as we have shown that the government actually does not need to pay the subsidy to firm 2. Its commitment to subsidize firm 2 is enough to change the incentive in the underlying game.

With a linear inverse market demand function, $P=a-q$, where, the notations have usual meanings, condition (7) holds provided $c_{2}<\frac{2 a+3 c_{1}}{5}$. It is easy to check that the critical value $\frac{2 a+3 c_{1}}{5}$ is less than the critical value of $c_{2}$ required to maintain a duopoly, i.e., $\frac{a+c_{1}}{2}$. Hence, it shows that this type of government policy can be welfare improving when the technologies of these firms are relatively close.

Further, one may do the same analysis by considering a generalized bargaining process like

$$
\max _{p}\left(p+\Pi_{1}^{0}\left(c_{1}, c_{1}\right)-\Pi_{1}^{0}\left(c_{1}, c_{2}\right)\right)^{\alpha}\left(\Pi_{2}^{0}\left(c_{1}, c_{1}\right)-F-p\right)^{1-\alpha}
$$

where $\alpha$ shows the bargaining power of the foreign firm. However, in this situation, only the domestic welfare will be affected by the bargaining powers of these firms. Higher bargaining power of the foreign firm leads to lower doemstic welfare. But, it can be easily checked that the other condition like the profitability of technology licensing is independent to the bargaining power. This finding is intuitive as the profitability of licensing depends on whether technology licensing increases industry profit or not and 
this has nohing to do with the bargaining powers of these firms.

\section{Conclusion}

In this paper we consider the possibility of a lump-sum subsidy in improving the domestic welfare. The imposition of a lump-sum subsidy does not affect the marginal incentives of the firms but it can significantly alter the underlying game. We find that if the initial technology gape is not too large between the firms, then the commitment to a subsidy policy by the domestic government can encourage technology licensing from the technologically efficient foreign firm to the technologically inefficient domestic firm. In particlar, the commitment of this government policy helps to remove the barrier created by the fixed cost of production to the technologically efficient domestic firm. Hence, due to this government policy announcement, the foeign firm faces threat of competition from the domestic firm and may prefer to license its superior technology to its inefficient competitor. As a result, the payoff of the domestic firm goes up and the domestic government does not need to pay any subsidy to its firm at all. Thus, this government policy can improve the domestic welfare by changing the incentives of different stages of the game. 


\section{REFERENCES}

1. Bhattacharjea, A., 1995, 'Strategic tariffs and endogenous market structures: Trade and industrial policies under imperfect competition', Journal of Development Economics 47: 287-312.

2. Brander, J. A. and B. J. Spencer, 1981, 'Tariffs and the extraction of foreign monopoly rents under potential entry', Canadian Journal of Economics 14: 371-89.

3. Brander, J. A. and B. J. Spencer, 1985, 'Export subsidies and industrial market share rivalry', Journal of International Economics 18: 83-100.

4. Dick, A., 1993, 'Strategic trade policy and welfare: The empirical consequence of crossownership', Journal of International Economics 35: 227-49.

5. Dixit, A., 1984, 'International trade policy for oligopolistic industries', Economic Journal (supplement) 94: 1-16.

6. Eaton, J. and G. J. Grossman, 1986, 'Optimal trade and industrial policy under oligopoly', Quarterly Journal of Economics 101: 383-406.

7. Kabiraj, T. and S. Marjit, 1992, 'To transfer or not to transfer the best technology under threat of entry: The case of price competition', in B. Dutta et al. (eds.), Game Theory and Economic Applications, Berlin: Springer-Verlag: 356-68.

8. Kabiraj, T. and S. Marjit, 1993, 'International technology transfer under potential threat of entry: A Cournot-Nash framework', Journal of Development Economics 42: $75-88$.

9. Kabiraj, T. and S. Marjit, 1998, 'Protecting consumers through protection: The role of tariff-induced technology transfer' Mimeo.

10. Katz, M. L. and C. Shapiro, 1985, 'On the licensing of innovations', Rand Journal of Economics 16: 504-20.

11. Lee, S., 1990, 'International equity markets and trade policy', Journal of International Economics 29: 173-84.

12. Marjit, S., 1990, 'On a non-cooperative theory of technology transfer', Economics Letters 33: 293-98. 
13. Marjit, S., T. Kabiraj and A. Mukherjee, forthcoming, 'Bilateral agreements in a multi-firm industry - Technology transfer and horizontal merger', Pacific Economic Review.

14. Neary, P., 1994, 'Cost asymmetries in international subsidy games: Shall governments help owners or losers?', Journal of International Economics 37: 197-218.

15. Qiu, L. D., 1994, Òptimal strategic trade policy under asymmetric information', Journal of International Economics 36: 333-54.

16. Spencer, B. J. and J. A. Brander, 1983, 'International R\&D rivalry and industrial strategy', Review of Economic Studies L(3): 707-22. 